\title{
Rainfall chemistry composition in two ecosystems in the northeastern Brazilian Amazon (Amapá State)
}

\author{
M. Cristina Forti, ${ }^{1}$ Adolpho J. Melfi, ${ }^{2}$ Rosana Astolfo, ${ }^{3}$ and Anne-Hélène Fostier ${ }^{4}$
}

\begin{abstract}
The rainfall chemical composition in two Amazonian ecosystems, a "terra firme" forest (dense tropical rain forest) and the "cerrado" (savanna) are presented. Both areas are located in the northeast Brazilian Amazon (Amapá State). This study evaluated the statistical differences in the rainfall chemistry, as well as the deposition through rainfall, for each ecosystem. The chemical species evaluated in the rainwater were $\mathrm{Na}^{+}, \mathrm{K}^{+}, \mathrm{Mg}^{2+}, \mathrm{Ca}^{2+}, \mathrm{NH}_{4}^{+}$, $\mathrm{Cl}, \mathrm{NO}_{3}^{-}, \mathrm{SO}_{4}^{2-}, \mathrm{Fe}^{3+}, \mathrm{Al}^{3+}, \mathrm{Zn}^{2+}$, and $\mathrm{Mn}^{2+}$ for both ecosystems. Factor analysis for the terra firme ecosystem indicated that there is a significant difference between the dry and wet periods in the rainfall chemical composition, indicating a biomass-burning signature $\left(\mathrm{K}^{+}\right.$in association with $\mathrm{Zn}^{2+}$ ). High deposition of solutes, except for $\mathrm{Mn}^{2+}$ and $\mathrm{Cl}^{\text {, was also observed }}$ during the dry period. Comparison between the terra firme and cerrado rainfall chemistry showed statistical differences in concentration for the marine species $\left(\mathrm{Na}^{+}\right.$and $\left.\mathrm{Cl}\right)$ and for the soil dust species $\left(\mathrm{Al}^{3+}, \mathrm{Fe}^{3+}\right.$, and $\left.\mathrm{Mn}^{2+}\right)$. The sea-salt and biogenic sources of chemical species in terra firme forest rainwater are equally important. The site nearer to the sea (cerrado) has rainfall chemistry dominated by species having marine origins. The terra firme forest also has rainfall chemistry dominated by marine origin species, although the biogenic and soil dust origin species are highly significant at this site. Also in the terra firme a biomass-burning signature was observed. The amount of sea salt deposited was more than $50 \%$ larger in the cerrado owing to its proximity to the shore.
\end{abstract}

\section{Introduction}

After 3 decades of studies, the Amazonian region still represents a challenge for environmental sampling and analysis. With 5.8 million square kilometers, the Amazon basin represents half of the world's remaining tropical forests together with a large area of tropical savanna (cerrado). Starting in the 1960s and 1970s, Brazilian Amazonia began undergoing large anthropogenic changes due to forest conversion to pasture and crops, as well as selective logging and mineral exploitation [Fearnside, 1993].

Changes in vegetative cover are thought to alter rainfall patterns in the Amazon; these changes in vegetation might also lead to alteration of the chemical composition of rainfall and of the atmospheric deposition to the ecosystem [Lesack and Melack, 1996]. However, questions remain about the sources of chemical species in rainfall and the spatial variability in its composition. Hence it is important that studies of rainfall chemical composition comprising different Amazonian sub-regions be developed. In this paper, results from the first data set for rainfall chemistry in the eastern Amazon is presented.

\footnotetext{
'MCT-INPE/DMS-NUPEGEL/USP, São José dos Campos, Brazil.

${ }^{2}$ ESALQ/USP-NUPEGEL/USP, Departamento de Solos e Nutrição de Plantas, Piracicaba, Brazil.

${ }^{3}$ IAG/USP-NUPEGEL/USP, Departamento de Ciências Atmosféricas, São Paulo, Brazil.

${ }^{4} \mathrm{IQ} /$ UNICAMP, Campinas, Brazil.

Copyright 2000 by the American Geophysical Union.
}

Paper number 2000JD900235

0148-0227/00/2000JD900235\$09.00
Among previous studies there are some that were done on short timescales in central Amazonia, within the Manaus region, during periods of high (March/April 1987) and low (July/August 1987) rainfall [Forti and Moreira-Nordemann, 1991; Andreae and Andreae, 1988; Andreae et al., 1990]. These works focused on the acidity of rainwater, as well as the differences between dry and wet season rainfall chemistry. Studies of longer periods are scarce but include those done at Lake Calado (central Amazon floodplain). Here Lesack and Melack [1991], on the basis of factor analysis of the rainfall chemical composition and from comparison between dry and wet seasons, found that dry deposition is not significant, except for phosphorous ( $\mathrm{P}$ ). These authors provided evidence of the seasonal importance of biogenic emissions of aerosols and reduced $\mathrm{S}$ and $\mathrm{N}$ gases from the Amazon rain forest to the atmosphere. Williams et al. [1997] have shown that for the same region, there is a rather constant source of aerosols in the atmosphere throughout the year and that these aerosols are primarily derived from oceanic and biogenic sources. These aerosols appeared to be the strongest determinant of solute composition of rainfall in central Amazonia. They also did not find a significant influence of biomass burning on the atmospheric concentration. Studies done by Filoso et al., [1999] at Negro River (Brazil) showed rainfall chemical composition within values observed by other authors. In this paper, we present an analysis of rainfall chemistry and solute deposition in two Amazonian ecosystems: tropical dense forest ("terra firme") and savanna ("cerrado"). Both sites are near the Amazon River estuary in Amapá State, located in northeastern Brazilian Amazonia. We examine the differences between cumulative rainfall samples collected by using bulk and wet-only collectors and the seasonal variations in rainfall chemistry for the terra firme ecosystem. The rainfall 
chemistry of the two ecosystems is also compared in order to characterize the primary sources of the principal ions for each ecosystem.

\section{Methods and Materials}

\subsection{Regional Setting}

The areas chosen for this study are situated in two different ecosystems in Amapá State. One is a dense tropical forest (terra firme site) in the Serra do Navio district (SNV) and the other is a tropical savanna (cerrado site) in the Tartarugalzinho district (TRT). The position of both sites as well as the main vegetation types are shown in Plate 1 [Faissol, 1966]; SNV is about $170 \mathrm{~km}$ away from the coast, while TRT is $80 \mathrm{~km}$ away.

The vegetative cover of Amapá State is variable. Savanna vegetation overlies the Barreira Formation (sedimentary rocks of the Tertiary) in a north-south direction. Dense forest, distinct from that covering the Amazon sedimentary basin, covers most of the state.

The climate of the region is tropical, with heavy rainfall from November to May. The main wet season occurs during the months of February, March, and April, while the driest months are July, August, and September [Ratisbona, 1976]. The mean temperature varies little through the year (between $20^{\circ} \mathrm{C}$ during the wet season and $30^{\circ} \mathrm{C}$ during the dry season).

\subsection{Sampling sites}

2.2.1. Serra do Navio District (SNV). The SNV region is covered with large extensions of terra firme forests, with patches of agricultural and pasture activities. There is also an area of about 4820 ha which was established in the 1940s as a reserve for Manganese extraction. The mining activities ended in 1999. Within this area, 1040 ha have been deforested for the extraction of manganese ( $420 \mathrm{ha})$ and the construction of a village and an industrial area $(620 \mathrm{ha})$. The SNV area was chosen owing to its geographic position, relative accessibility, and the possibility of conductintg studies of anthropogenic impact on biogeochemical cycles in a controlled small catchment. In this region, the altitude varies from $90 \mathrm{~m}$, as in the Amapari River valley, to $350 \mathrm{~m}$ in the highest hills of the district. The vegetation is typical of humid tropical forest with two main horizontal strata: a tree layer with emergent trees of up to $40 \mathrm{~m}$ tall and a lower layer mainly composed of palms. Soils are characterized by a nonhomogeneous profile with 1 to $3 \mathrm{~m}$ of dystrophic red-yellowish latosols (oxysols) that cover a hardened ferruginous horizon of 4- to 6-m thickness. Beneath the ferruginous horizon is a saprolitic layer of 30 - to 45-m thickness, originally from the underlying rocks of the region.

During the sampling period (July 1993 until June 1997) the average temperature was $24^{\circ} \mathrm{C}$, with minimum mean values between $20^{\circ} \mathrm{C}$ and $23^{\circ} \mathrm{C}$ and maximum mean values between $28^{\circ} \mathrm{C}$ and $32^{\circ} \mathrm{C}$. Precipitation occurred during all sampled months, and the maximum rainfall was $366 \mathrm{~mm}$ in April 1996, while a minimum value of $7.7 \mathrm{~mm}$ occurred in June 1997 [Melfi, 1997].

2.2.2. Tartarugalzinho District (TRT). TRT is located approximately $150 \mathrm{~km}$ northeast of SNV and is at sea level. This region, although difficult for fieldwork owing to poor road access and high risk of malaria, was selected for the main project because of the existence of gold extraction by manual processing (garimpos), using $\mathrm{Hg}$ for amalgamation. In this region, the dominant vegetation is savanna with areas of pasture. There are no detailed data on the physiography and occupation. The soils are predominantly lateritic, with euthrophic gley and dystrophic and euthrophic alluvion being the common types.

The mean maximum and mean minimum temperatures varied between $30^{\circ} \mathrm{C}$ and $35^{\circ} \mathrm{C}$ and between $20^{\circ} \mathrm{C}$ and $23^{\circ} \mathrm{C}$, respectively. The maximum rainfall was $344 \mathrm{~mm}$ in January 1997, and there were large periods with no rainfall, such as June and July 1996.

\subsection{Sampling Collection and Analysis}

The data presented here were obtained as part of a larger project (PADCT/CIAMB-CNPq 620375/92.9) whose main objective was to evaluate the $\mathrm{Hg}$ cycle in tropical forest within natural and deforested small catchments [Forti et al., 1997, 2000; Melfi, 1997; Fostier et al., 1999].

In SNV the collectors (wet only and bulk) were installed in an open area on a hilltop (289-m height; $00^{\circ} 53^{\prime} 12^{\mathrm{n}} \mathrm{N}$, $51^{\circ} 58.59^{n} \mathrm{~W}$ ), and sampled from July 1993 to June 1997 with two interruptions, one from June 1994 to May 1995 and another from November 1995 to January 1996 . Wet-only and bulk collectors were used simultaneously from May 1996 to June 1997; for the remaining period only bulk collectors were available. Description of the collectors as well as procedures for cleaning them are presented elsewhere [Forti et al., 1997, 2000]. The sampling period was shorter at TRT than at SNV, lasting from January 1996 to June 1997, and sampling was done with both collectors installed in an open pasture area $\left(1^{\circ} 37.05^{\circ} \mathrm{N}, 51^{\circ} 05^{\prime} 27^{\circ} \mathrm{W}\right)$.

Weekly accumulated rainfall samples were collected at SNV, totaling 107 useful samples, during 36 collecting months, and at TRT they were obtained every 15-20 days, depending on the availability of transport giving, after 18 sampling months, a total of 13 useful rainwater samples.

To calculate the volume-weighted mean concentration, it was necessary to determine the rainfall volume (sampled volume). At SNV, the sampled volumes were measured gravimetrically by weighting the collection bottles with samples. This procedure gave a precision of $10 \%$. In TRT a scale was not available to weight the samples; so we used the rainfall totals obtained from the time series at the Amapa station. The rainfall amount for this site was considered to be the monthly mean values obtained from a time series of 8 years at the Amapa station (see the relative location in Plate 1) [Melfi, 1997]. These values were also used for the weighted mean value calculations.

The sampling containers were made of polyethylene and were protected against direct exposure to sunlight as much as possible. All containers were rinsed abundantly with deionized water before each collection. The rainfall samples were preserved in the field with thymol [Gillet and Ayers, 1991]. The samples were filtered through membrane filters $(0.22-\mu \mathrm{m}$ pore diameter) to separate the soluble fraction and to eliminate bacteria. In order to stabilize the chemical species, the samples were preserved on the day of collection according to the recommendation of Appelo and Postma [1994]. After preservation, the samples were stored at $4^{\circ} \mathrm{C}$ until the analysis. One unfiltered aliquot was used for the $p \mathrm{H}$ measurement with a DIGIMED model DM2 $1 p \mathrm{H}$ meter with a combined glass electrode $\mathrm{Ag} / \mathrm{AgCl}$. Conductivity was 


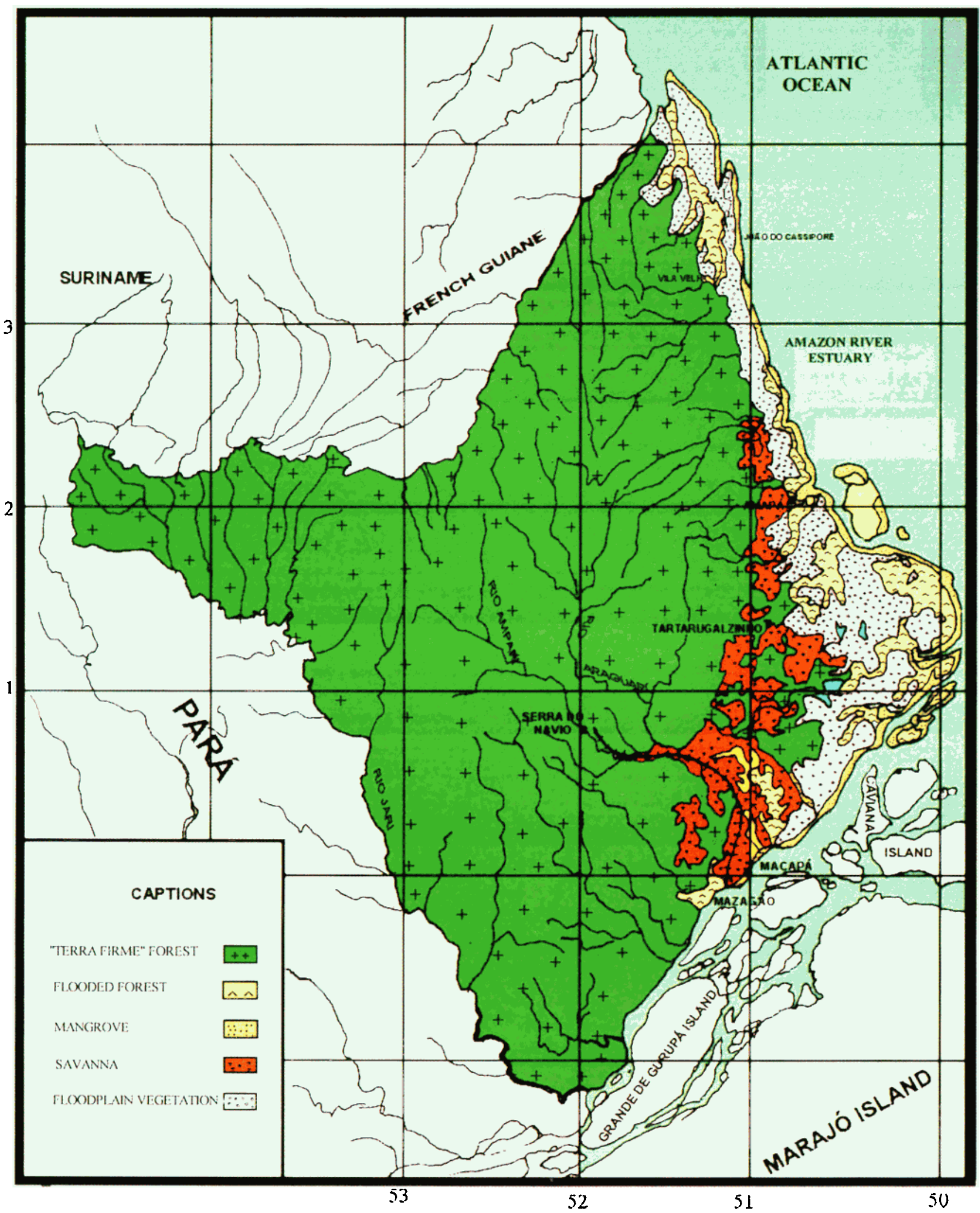

Plate 1. Relative position of the two areas (Serra do Navio (SNV) and Tartarugalzinho (TRT)) and the main types of vegetation distribution in Amapá State, Brazil [Faissol, 1966]. 
measured with a field conductivity meter (DIGIMED) and the alkalinity employing acid Gran titration with a $10^{-2} \mathrm{~N} \mathrm{H}_{2} \mathrm{SO}_{4}$ solution. The remaining chemical analyses were performed as soon as possible, most of them within 3 months after collection.

The principal ions were determined by using ion chromatography (DIONEX DX-500). For the major cations we used a C12 separator column with methanosulfonic acid as eluent. For anions an AS4A separator column with carbonate/bicarbonate as eluent was used. Conductivity detection was used for cations and anions. For the metals we used UV/Vis detector, CS5A separator column, post-column derivatization with 4-(2-piridilasol) resorcinol and pyridine dicarboxylic acid as eluent, and a wavelength of $530 \mathrm{~nm}$; for $\mathrm{Al}^{3+}$ the column was the same as for the other metals and the eluent was sulfuric acid/ammonium sulfate, with post-column reaction with pyrocatecol violet and a wavelength of $530 \mathrm{~nm}$. The precision was within $10 \%$ on average. The accuracy was checked against certified reference material samples (TM26 and TM28, trace metal fortified water, National Water Research Institute, Ontario, Canada, 1995) and standards from the United Kingdom Institute of Hydrology hydrochemistry laboratory [Robson and Neal, 1997]. Details of these collections and chemical analysis are found in the work of Forti et al. [1997, 2000].

\section{Results and Discussion}

\subsection{Rainfall Chemical Composition at SNV and TRT}

Rainfall samples collected at SNV and TRT were divided into two groups: those collected in bulk collectors and the ones collected with wet-only collectors. A test of equality was applied to the data set obtained simultaneously with both collectors to verify if the mean concentration values obtained with each collector type were statistically different or not. The test was done with a probability confidence interval of $95 \%$ and significance level of $5 \%$. The results of these calculations did not indicate any significant statistical differences in the rainfall chemical composition determinations between both collector types, showing the low importance of dry deposition over open collectors for these samples. Therefore we only discuss results obtained with bulk collectors, since they are the most widely used in this type of work and we had a longer time series of bulk collections.

The statistics of the rainfall chemical composition, in $\mu$ eq $L^{-1}$, are shown in Table 1 for the SNV and TRT sites. The mean $p \mathrm{H}$ values, obtained from the $\left[\mathrm{H}^{+}\right]$volume-weighted mean, are 5.09 and 5.49 for SNV and TRT, respectively. These values are slightly higher than the values found in central Amazonia [Forti and Moreira-Nordemann, 1991; Talbot et al., 1990, Lesack and Melack, 1991]. The electrochemical difference [Appelo and Postma, 1994] at SNV is $38 \%$ and is attributed to organic acids not measured in these samples. This difference represents a concentration of $0.34 \mathrm{mmol} \mathrm{L}^{-1}$, which is lower than the organic carbon concentration mean values of $0.86 \mathrm{mmol} \mathrm{L}^{-1}$ found for this region [Eyrolle et al., 1996; M. F. Benedetti, personal communication, 1997]. This point is discussed elsewhere by Forti et al. [1997]. At TRT the rainwaters have an electrochemical balance of $7 \%$.

The rainfall solute concentration results obtained in this work can be compared with some values for tropical forests and savanna in other regions (Table 2). The comparison highlights the large variability in the rainfall chemical composition for the region. The values obtained in this work are, in general, higher than the ones recently found in central Amazonia, except for $\mathrm{H}^{+}$and $\mathrm{NH}_{4}^{+}$[Williams et al., 1997; Lesack and Melack, 1991; Filoso et al., 1999], and not very different from those found by Forti and Neal [1992]. Regarding the savanna ecosystem, except for $\mathrm{H}^{+}, \mathrm{NH}_{4}^{+}$, and $\mathrm{NO}_{3}^{-}$, all other ions have higher concentrations when compared with the Venezuelan savanna [Morales et al., 1995]. Concerning the other tropical regions, comparison with our results shows that they are within the same concentration range.

\subsection{Rainfall Chemistry Seasonality in SNV District}

In the Amazon region the main characteristic of the seasonality is the rainfall amount differences during the rainy months (wet season) and dry or less rainy months (dry

Table 1. Statistics for Rainfall Chemical Composition $\left(\mu \mathrm{eq} \mathrm{L}^{-1}\right)$ for SNV and TRT

\begin{tabular}{|c|c|c|c|c|c|c|c|c|c|c|c|c|c|}
\hline & $\mathbf{H}^{+}$ & $\mathrm{Na}^{+}$ & $\mathrm{K}^{+}$ & $\mathrm{Mg}^{2+}$ & $\mathrm{Ca}^{2+}$ & $\mathrm{NH}_{4}^{+}$ & $\mathrm{Cl}^{\circ}$ & $\mathrm{NO}_{3}^{-}$ & $\mathrm{SO}_{4}{ }^{2-}$ & $\mathrm{Al}^{3+}$ & $\mathrm{Fe}^{3+}$ & $\mathrm{Mn}^{2+}$ & $\mathrm{Zn}^{2+}$ \\
\hline \multicolumn{14}{|c|}{ Serra do Navio $(P=2143 \mathrm{~mm})$} \\
\hline$N$ & 96 & 98 & 98 & 99 & 61 & 96 & 95 & 97 & 99 & 60 & 77 & 77 & 64 \\
\hline VWM & 8.21 & 16.6 & 4.72 & 9.54 & 12.7 & 3.47 & 16.9 & 6.09 & 6.24 & 7.05 & 0.84 & 1.16 & 4.92 \\
\hline ARM & 9.35 & 22.4 & 6.24 & 11.3 & 11.7 & 4.46 & 22.8 & 6.26 & 7.34 & 6.72 & 1.02 & 1.50 & 5.42 \\
\hline Std & 16.3 & 17.6 & 7.81 & 10.1 & 13.9 & 12.6 & 20.2 & 9.85 & 6.74 & 3.78 & 1.47 & 1.48 & 5.52 \\
\hline Min & 0.001 & 3.48 & 0.00 & 0.00 & 0.00 & 0.00 & 1.05 & 0.00 & 0.76 & 0.45 & 0.03 & 0.26 & 0.20 \\
\hline $\operatorname{Max}$ & 95.5 & 128 & 45.1 & 90.2 & 94.5 & 118 & 158 & 61.5 & 42.0 & 15.5 & 11.7 & 7.38 & 27.5 \\
\hline \multicolumn{14}{|c|}{ Tartarugalzinho $(P=2154 \mathrm{~mm})$} \\
\hline$N$ & 11 & 13 & 13 & 13 & 13 & 13 & 13 & 13 & 13 & 13 & 13 & 13 & 11 \\
\hline VWM & 3.11 & 28.0 & 2.76 & 6.42 & 7.80 & 13.1 & 29.0 & 3.60 & 5.30 & 1.47 & 0.09 & 0.08 & 3.70 \\
\hline ARM & 2.83 & 25.7 & 3.96 & 6.24 & 9.68 & 15.6 & 25.5 & 4.58 & 5.50 & 1.71 & 0.18 & 0.14 & 3.78 \\
\hline Std & 2.52 & 11.8 & 3.39 & 3.38 & 5.18 & 21.6 & 13.4 & 6.05 & 2.34 & 1.17 & 0.24 & 0.10 & 2.98 \\
\hline Min & 0.25 & 7.58 & 1.42 & 1.90 & 4.10 & 0.75 & 7.85 & 0.91 & 2.16 & 0.00 & 0.00 & 0.00 & 0.58 \\
\hline Max & 7.76 & 45.8 & 14.4 & 13.9 & 19.7 & 83.3 & 47.9 & 22.8 & 9.40 & 3.69 & 0.66 & 0.30 & 10.9 \\
\hline
\end{tabular}

$N$, sample number, VWM, volume-weighted mean; ARM, arithmetic mean; Std, standard deviation; Min, minimum value; Max, maximum value; $P$, rainfall (millimeters). 
Table 2. Rainfall Concentration Values of the Principal Ions in Different Tropical Regions $\left(\mu \mathrm{eq} \mathrm{L}^{-1}\right)$

\begin{tabular}{lllllllllll}
\hline Ions & SNV & TRT & $\begin{array}{l}\text { Venezuela } \\
\text { (Savanna) }\end{array}$ & $\begin{array}{l}\text { Congo } \\
\text { (Forest) }\end{array}$ & $\begin{array}{l}\text { Puerto } \\
\text { Rico } \\
\text { (Forest) }\end{array}$ & $\begin{array}{l}\text { Costa } \\
\text { Rica } \\
\text { (Forest) }\end{array}$ & $\begin{array}{l}\text { Central } \\
\text { Amazonia } \\
\text { (Forest) }\end{array}$ & $\begin{array}{l}\text { Central } \\
\text { Amazonia } \\
\text { (Forest) }\end{array}$ & $\begin{array}{l}\text { Central } \\
\text { Amazonia } \\
\text { (Forest)* }\end{array}$ & $\begin{array}{l}\text { Negro } \\
\text { River }\end{array}$ \\
\hline $\mathrm{Na}^{+}$ & 16.6 & 16.9 & 9.6 & 10.1 & 71 & 38.9 & 2.4 & 2.5 & 16.3 & 5.1 \\
$\mathrm{~K}^{+}$ & 4.72 & 2.53 & 1.3 & 2.0 & 2.4 & 2.3 & 0.8 & 0.7 & 4.22 & 0.9 \\
$\mathrm{Ca}^{2+}$ & 12.7 & 8.06 & 2.5 & 9.3 & 17 & 7.1 & 2.4 & 2.1 & 5.74 & 5.9 \\
$\mathrm{Mg}^{2+}$ & 9.54 & 4.84 & 0.2 & - & 18 & 10.1 & 0.9 & 1.5 & 2.06 & 1.5 \\
$\mathrm{NH}_{4}^{+}$ & 3.47 & 6.82 & 24.6 & - & 1.7 & 8.7 & 3.0 & 6.6 & 2.22 & 2.2 \\
$\mathrm{NO}_{3}{ }^{+}$ & 6.09 & 6.52 & 12.0 & 8.6 & 2.8 & 5.36 & 4.2 & 3.5 & - & 2.7 \\
$\mathrm{Cl}^{+}$ & 16.9 & 26.4 & 12.1 & 13.3 & 88 & 47.6 & 4.6 & 4.7 & 11.4 & 3.1 \\
$\mathrm{SO}_{4}{ }^{2}$ & 6.24 & 8.48 & 63.6 & 10.5 & 31 & 17.7 & 2.0 & 4.5 & 7.81 & 2.1 \\
$\mathrm{H}^{+}$ & 8.21 & 3.23 & 5.4 & 18.1 & 7.3 & 5.4 & 17.0 & 12.9 & 5.34 & 9.8 \\
$\mathrm{Reference}$ & this & this & Morales et & Lacaux & McDow & Eklund & Williams & Lesack and & Forti and & Filoso \\
& work & work & al. [1995] & et al. & ell et & et al. & et al. & Melack & Neal & et al. \\
& & & & {$[1992]$} & al. & {$[1997]$} & {$[1997]$} & {$[1991]$} & {$[1992]$} & {$[1999]$} \\
& & & & & {$[1990]$} & & & & & \\
\hline
\end{tabular}

*Value obtained from wet plus dry seasons mean values

season). Therefore in general, when the rainfall amount is large, the amount of chemicals introduced into the ecosystem through rainfall is proportionately larger. Another characteristic, this one anthropogenic in its origin, is the biomass burning during the driest months, both in forest and in crop/pasture regions. Here we analyze the seasonality of rainfall chemistry only at $\mathrm{SNV}$, because at this site we have a sufficient number of samples covering 3 years. In order to perform this analysis, the data set was divided into two groups: one covering the wettest semester (here named wet season: January-June) and the other covering the less rainy months (here named dry season: July-December). The statistics for both groups, as well as the deposition of the chemical species, are shown in Table 3. A reasonable estimate of the annual deposition is given by the sum of wet and dry depositions.

The comparison between both periods was done through a test of equality with a probability of $95 \%$ and a confidence level of 5\% presented as box-and-whiskers plots, exemplified by six chemicals in Figure 1. Significant statistical differences were observed in the mean concentration values for $\mathrm{K}^{+}, \mathrm{NO}_{3}$, $\mathrm{SO}_{4}^{2-}, \mathrm{Al}^{3+}, \mathrm{Mn}^{2+}$, and $\mathrm{Zn}^{2+}$. For the other chemical species, no statistically significant differences were observed. These differences are reflected in the deposition, which is larger for these same chemicals during the wet period, except for $\mathrm{Al}^{3+}$. Therefore this test, along with the deposition totals for each period, indicates that, irrespective of the effect of high rainfall amounts introducing larger amounts of chemicals, there exists a real difference in the rainfall composition between the periods of high rainfall (wet) and low rainfall (dry).

To investigate the nature of these seasonal differences, we did a factor analysis to characterize the possible influence of the different sources in the variance of the chemical concentrations. This analysis was done by using a varimax rotated factor matrix with extraction of four factors explaining $77 \%$ and $73 \%$ of the variance for the wet and dry penods,

Table 3. Statistics for Rainfall Chemistry in Serra do Navio Covering the Wet Season and the Dry season $\left(\mu e q L^{-1}\right)$

\begin{tabular}{|c|c|c|c|c|c|c|c|c|c|c|c|c|c|}
\hline & $\mathrm{H}^{+}$ & $\mathrm{Na}^{+}$ & $\mathbf{K}^{+}$ & $\mathrm{Mg}^{2+}$ & $\mathrm{Ca}^{2+}$ & $\mathrm{NH}_{4}^{+}$ & $\mathrm{Cl}^{-}$ & $\mathrm{NO}_{3}$ & $\mathrm{SO}_{4}{ }^{2-}$ & $\mathrm{Al}^{3+}$ & $\mathrm{Fe}^{3+}$ & $\mathrm{Mn}^{2+}$ & $\mathrm{Zn}^{2+}$ \\
\hline \multicolumn{14}{|c|}{ Wet Period $(P=1381 \mathrm{~mm})$} \\
\hline$N$ & 40 & 40 & 40 & 40 & 36 & 35 & 39 & 35 & 39 & 26 & 33 & 33 & 29 \\
\hline VWM & 6.19 & 15.1 & 3.43 & 9.80 & 14.6 & 2.56 & 15.7 & 2.53 & 3.96 & 8.16 & 0.72 & 0.92 & 3.78 \\
\hline ARM & 6.17 & 18.4 & 4.47 & 12.7 & 15.7 & 2.08 & 19.5 & 1.82 & 4.84 & 8.43 & 0.72 & 1.00 & 3.92 \\
\hline Std & 6.37 & 12.2 & 4.14 & 11.2 & 20.6 & 1.81 & 13.5 & 2.91 & 3.32 & 3.45 & 0.33 & 0.70 & 5.52 \\
\hline DEP & 0.09 & 4.79 & 1.85 & 1.64 & 4.04 & 0.64 & 7.70 & 2.17 & 2.63 & 1.01 & 0.19 & 0.35 & 1.71 \\
\hline \multicolumn{14}{|c|}{ Dry Period $(P=762 \mathrm{~mm})$} \\
\hline$N$ & 54 & 60 & 62 & 63 & 63 & 58 & 58 & 59 & 61 & 37 & 46 & 46 & 38 \\
\hline VWM & 5.13 & 18.5 & 6.29 & 9.50 & 10.1 & 3.10 & 18.2 & 5.21 & 6.43 & 6.03 & 0.99 & 1.46 & 6.56 \\
\hline ARM & 6.75 & 23.1 & 7.78 & 11.1 & 10.1 & 3.61 & 22.5 & 6.49 & 8.02 & 5.43 & 0.96 & 1.84 & 6.88 \\
\hline Std & 11.7 & 14.5 & 9.93 & 10.0 & 9.10 & 5.50 & 15.0 & 7.77 & 6.04 & 3.36 & 0.96 & 1.76 & 5.46 \\
\hline DEP & 0.04 & 3.44 & 1.87 & 0.88 & 1.54 & 0.43 & 4.92 & 2.46 & 2.35 & 0.41 & 0.14 & 0.31 & 1.63 \\
\hline \multicolumn{14}{|c|}{ Total Period $(\mathrm{P}=2143 \mathrm{~mm})$} \\
\hline TOTDEP & 0.13 & 8.03 & 3.72 & 2.52 & 5.58 & 1.07 & 12.6 & 4.63 & 4.98 & 1.42 & 0.32 & 0.66 & 3.34 \\
\hline
\end{tabular}

N, sample number, VWM, volume-weighted mean; ARM, arithmetic mean; Std, standard deviation; DEP, deposition of chemical species $\left(\mathrm{kg} \mathrm{ha}^{-1}\right)$; $\mathrm{P}$, rainfall (millimeters); TOTDEP, total annual deposition $\left(\mathrm{kg} \mathrm{ha}^{-1} \mathrm{yr}^{-1}\right)$. 

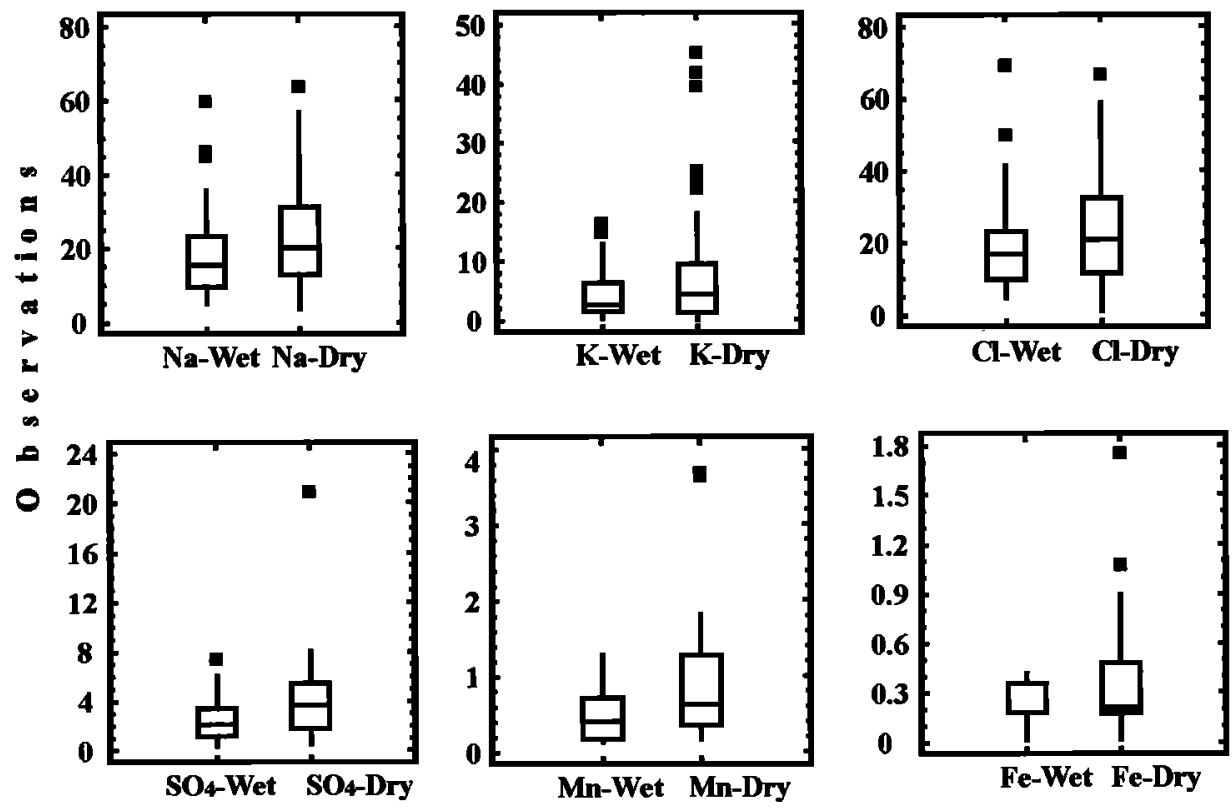

Figure 1. Multiple box-and-whiskers plots comparing mean concentration ( $\mu$ eq $\mathrm{L}^{-1}$ ) values for Serra do Navio samples during the wet and dry periods for $\mathrm{K}^{++} \mathrm{SO}_{4}{ }^{2-}$, and $\mathrm{Mn}^{2+}$ (statistically significant differences) and for $\mathrm{Na}^{+}, \mathrm{Cl}^{-}$and $\mathrm{Fe}^{3+}$ (no statistically significant differences).

respectively. These results, with communality and percentage values, are shown in Tables 4 and 5 for the wet and dry seasons, respectively.

The factor analysis results show that for both the wet and the dry season the variance percentage values have similar distributions among the factors. However, for each season the corresponding factors have a different structure. Low communality values for $\mathrm{Zn}^{2+}$ during the dry period and for $\mathrm{Mn}^{2+}$ during the wet period were observed.

For the wet period, the association between factors and specific natural sources is not well defined. If we discard the $\mathrm{Fe}^{3+}$ loading, because its communality value is low, both factors 2 and 3 can be associated with biomass tracers such as
$\mathrm{K}^{+}$and $\mathrm{Mg}^{2+}$ originating from biotic sources (e.g., aerosols containing pollen, fungi, leaf fragment, etc.) and $\mathrm{NH}_{4}^{+}$and $\mathrm{NO}_{3}{ }^{-}$associated with land-air exchange via nitrification and denitrification [Matson et al., 1999]. Factor 1 shows a mixture of marine $\left(\mathrm{Cl}^{-}\right.$and $\left.\mathrm{SO}_{4}{ }^{2-}\right)$ and soil dust $\left(\mathrm{Al}^{3+}\right)$ sources which allow us to associate this factor with regional transport that brings chemicals from other regions and that are eventually deposited at this site. Factor 4 has a strong loading on $\mathrm{Zn}^{2+}$, with an association with $\mathrm{Al}^{3+}$ which indicates a soil dust source.

For the dry season, there is no clear association between one factor and one specific natural source. Factor 1 has a large loading on chemicals of marine origin, as well as on $\mathrm{Mn}^{2+}$, the

Table 4. Varimax Rotated Factor Matrix, Communality and Percentage of Variance for the Wet Period for SNV Rainwater.

\begin{tabular}{|c|c|c|c|c|c|}
\hline & \multicolumn{4}{|c|}{ Factor } & \multirow[b]{2}{*}{ Communality } \\
\hline & 1 & 2 & 3 & 4 & \\
\hline $\mathrm{Na}^{+}$ & $0.85746^{*}$ & 0.31354 & -0.17518 & -0.16818 & 0.89252 \\
\hline $\mathbf{K}^{+}$ & 0.15660 & $0.84990^{*}$ & -0.28835 & 0.05709 & 0.83327 \\
\hline $\mathrm{Mg}^{2+}$ & 0.20007 & $0.83886^{*}$ & -0.39525 & 0.02801 & 0.90071 \\
\hline $\mathrm{Ca}^{2+}$ & $0.91280^{*}$ & -0.14067 & 0.03798 & 0.37801 & 0.99732 \\
\hline $\mathrm{NH}_{4}^{+}$ & 0.07255 & -0.31894 & $0.75044^{*}$ & 0.22948 & 0.72281 \\
\hline $\mathrm{Cl}$ & $0.90414^{*}$ & 0.23464 & -0.05673 & -0.11512 & 0.88899 \\
\hline $\mathrm{NO}_{3}^{-}$ & -0.07593 & 0.01639 & $0.95080^{*}$ & -0.13856 & 0.92926 \\
\hline $\mathrm{SO}_{4}^{2-}$ & $0.87030^{*}$ & 0.24454 & 0.07515 & -0.15641 & 0.84733 \\
\hline $\mathrm{Al}^{3+}$ & 0.58499 & -0.04831 & 0.25496 & $0.62760^{*}$ & 0.80344 \\
\hline $\mathrm{Fe}^{3+}$ & 0.12921 & $0.64742^{*}$ & 0.28169 & -0.22903 & 0.56766 \\
\hline $\mathrm{Mn}^{2+}$ & 0.11819 & 0.36870 & 0.02652 & -0.42992 & 0.33544 \\
\hline $\mathrm{Zn}^{2+}$ & -0.8586 & 0.03509 & -0.03406 & $0.84068^{*}$ & 0.71651 \\
\hline Variance $\%$ & 34 & 21 & 13 & 9 & \\
\hline
\end{tabular}

*Considered high loading values. 
Table 5. Varimax Rotated Factor Matrix, Communality and Percentage of Variance for the Dry Period for SNV Rainwater

\begin{tabular}{llllll}
\hline & \multicolumn{5}{c}{ Factor } \\
\cline { 2 - 5 } & 1 & 2 & 3 & 4 & \multirow{2}{*}{ Communality } \\
\hline $\mathrm{Na}^{+}$ & $0.86360^{*}$ & 0.13514 & -0.15273 & 0.09905 & 0.79720 \\
$\mathrm{~K}^{+}$ & 0.19232 & $0.90036^{*}$ & -0.05887 & -0.01393 & 0.85130 \\
$\mathrm{Mg}^{2+}$ & $0.59799^{*}$ & $0.50442^{*}$ & 0.03230 & 0.28243 & 0.69283 \\
$\mathrm{Ca}^{2+}$ & 0.12916 & 0.21896 & -0.02747 & $0.88877^{*}$ & 0.85529 \\
$\mathrm{NH}_{4}^{+}$ & 0.06324 & 0.00376 & -0.71416 & 0.31379 & 0.61250 \\
$\mathrm{Cl}^{+}$ & $0.95592^{*}$ & 0.13076 & 0.03291 & -0.05707 & 0.93523 \\
$\mathrm{NO}_{3} \mathrm{SO}_{4}^{2-}$ & 0.20438 & -0.16668 & -0.50289 & -0.35027 & 0.44514 \\
$\mathrm{Al}^{3+}$ & $0.89738 *$ & 0.12623 & -0.16968 & -0.10379 & 0.86080 \\
$\mathrm{Fe}^{3+}$ & -0.24718 & 0.46907 & $0.72460^{*}$ & 0.03566 & 0.80744 \\
$\mathrm{Mn}^{2+}$ & 0.30139 & -0.19620 & $0.67185^{*}$ & 0.19037 & 0.61696 \\
$\mathrm{Zn}^{2+}$ & $0.72840^{*}$ & -0.14361 & 0.17317 & 0.38446 & 0.72899 \\
$\mathrm{Variance}^{2+}$ & 0.06695 & $0.65120^{*}$ & 0.14141 & 0.22329 & 0.49974 \\
\hline & 33 & 19 & 12 & 9 & \\
\hline
\end{tabular}

*Considered high loading values

latter being associated with soil dust due to the mining activities in the neighborhood. Factor 2 has a high loading on chemicals from biomass sources like $\mathrm{Mg}^{2+}$ and $\mathrm{K}^{+}$, as well as chemicals from soil dust, such as $\mathrm{Al}^{3+}$ (smaller loading). In addition, in factor $2, \mathrm{Zn}^{2+}$ has a large loading value. According to Yamasoe [1994], Zn may be a good tracer for biomass burning when associated with $\mathrm{K}$, while other authors [Gaudichet et al., 1995] have found $\mathrm{Zn}$ in biomass burning aerosols in the African savanna. Consequently, we associate this factor with biomass burning, because $\mathrm{Zn}^{2+}$ and $\mathrm{K}^{+}$appear in the same factor and during the dry season. This association is shown in Figure 2 through a scatter plot diagram for the total, dry, and wet periods. Factor 3 shows a large loading in $\mathrm{Al}^{3+}$ and $\mathrm{Fe}^{3+}$, and factor 4 has a high loading in $\mathrm{Ca}^{2+}$, which allow us to associate these factors with soil dust.

Significant differences between the dry and wet seasons were observed relating to the deposition as well as to the sources of chemical species in rainfall. The differences in the sources refer to their intensity and significance. From the factor analysis, it is observed that the loading distribution
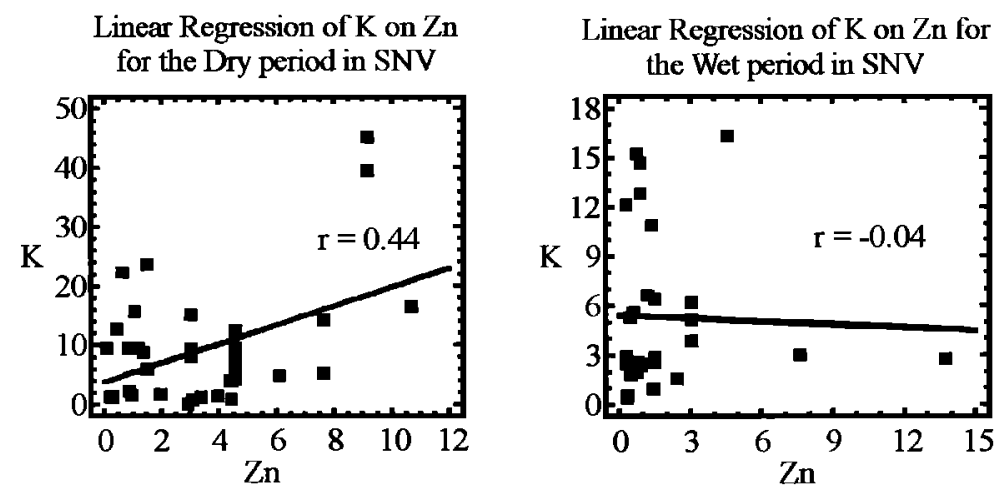

Linear Regression of K on Zn for the Total period in SNV

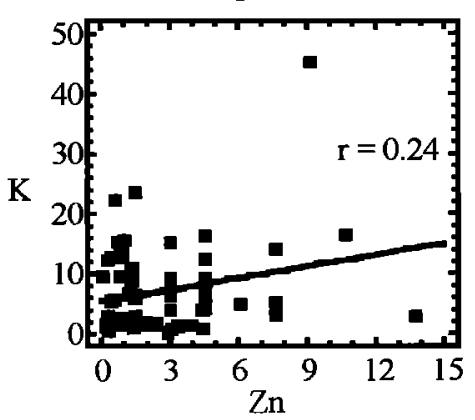

Figure 2. Scatter plot diagrams for $\mathrm{K}^{+}$versus $\mathrm{Zn}^{2+}$ in Serra do Navio (SNV) rainfall water with linear regression lines and coefficients for the total, wet, and dry periods. 

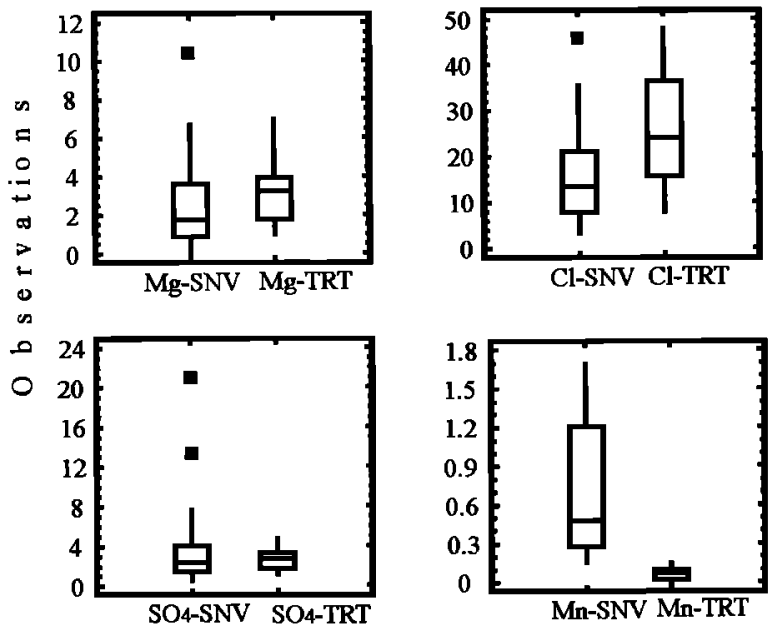

Figure 3. Multiple box-and-whiskers plots for the weighted mean values ( $\mu \mathrm{eq} \mathrm{L}^{-1}$ ) for Serra do Navio (SNV) and Tartarugalzinho (TRT) for $\mathrm{Mg}^{2+}$ and $\mathrm{Cl}^{-}$(no statistically significant differences) and for $\mathrm{SO}_{4}{ }^{2-}$ and $\mathrm{Mn}^{2+}$ (statistically significant differences).

among the different factors and the percentage of the explained variance of the chemical composition are different for each period. The marine source is the most important, and its loading is equivalent for both periods. However, the biogenic and soil dust contributions are different for each period, and their contribution is significantly higher during the dry season. Furthermore, we observed an additional source that may be associated with biomass burning which is active during the dry season.

\subsection{Comparison Between SNV and TRT Rainwater Chemistry}

3.3.1. Concentration of the chemical species in the SNV and TRT rainfall. The data set from SNV and TRT was submitted to a hypothesis test in order to verify the existence of significant differences between the mean values of each chemical for each site. The tests were performed with a confidence interval of $95 \%$ probability with a significance level of 5\%; these results are illustrated in Figure 3 as multiple box-and-whiskers plots for $\mathrm{Cl}^{-}$and $\mathrm{Mn}^{2+}$ (statistically different) and $\mathrm{Mg}^{2+}$ and $\mathrm{SO}_{4}{ }^{2-}$ (not statistically different). In this test, $\mathrm{NH}_{4}{ }^{+}$and $\mathrm{NO}_{3}{ }^{-}$were not included, since the sampling frequencies were different. These plots show significant differences for the volume-weighted mean values of $\mathrm{Cl}^{-}$and $\mathrm{Mn}^{2+}$. The observed differences in $\mathrm{Cl}^{-}$concentration can be attributed to losses due to fractionation during the transport inland from the Atlantic coast. For $\mathrm{Mn}^{2+}$, the difference is attributed to its enrichment in the SNV region due to mining activities, which represents an extra source of this element.

From the hypothesis test, it is possible to infer that the principal difference in rainfall composition between the two sites is due to the sea-salt and soil dust contributions. Hence it is appropriate to investigate the structure of these differences by examining the variability of the rainfall composition and, therefore, to characterize the sources. Therefore a regression analysis and a hypothesis test between the sea-salt constituents and reference species in the precipitation chemistry were applied. According to Keene et al. [1986], this calculation (Table 6) can give information about the sea-salt contribution. These authors stated that if the slope and the intercept are not significantly different from the seawater ratio and zero, respectively, it is inferred that all of both species originate from sea salt. This is the case for $\mathrm{Mg}^{2+}$ in TRT and $\mathrm{Cl}^{\mathrm{l}}$ for both sites (SNV and TRT). For the intercept significantly different from zero and the slope significantly the same as the seawater ratio, there is a nonvariable non-seasalt effect, the magnitude of which is nonvariable and independent of the sea-salt component, as is observed for $\mathrm{SO}_{4}^{2-}$ in the TRT samples. If, however, both slope and intercept are significantly different from zero, then either fractionation and/or a variable non-sea-salt effect is present, a result which is observed for the other ions in both sites. Therefore from these results we can infer that there is a strong sea-salt influence on TRT rainwater chemical composition, combined with a variable non-sea-salt source. In the sequel, the sea-salt and non-sea-salt fractions (Table 7) of $\mathrm{Na}^{+}, \mathrm{K}^{+}$, $\mathrm{Mg}^{2+}, \mathrm{Ca}^{2+} \mathrm{Cl}$, and $\mathrm{SO}_{4}^{2-}$ for the volume-weighted mean values, using $\mathrm{Na}^{+}$as a reference [Williams et al., 1997], were calculated. $\mathrm{A} \mathrm{Na}^{+}$excess related to $\mathrm{Cl}^{-}$in the $\mathrm{SNV}$ rainwater was observed. To balance this difference, a correction was done imposing the sea-salt ratio $\mathrm{Cl}^{-} \mathrm{Na}^{+}=1.17$, which means that all $\mathrm{Cl}^{-}$has marine origin. In this case, $\mathrm{a} \mathrm{Na}^{+}=14.4 \mu \mathrm{eq} \mathrm{L}^{-1}$ mean concentration was used as the $\mathrm{Na}^{+}$sea-salt fraction. As is shown in Table 7, for SNV rainwater sea-salt fractions of $87 \%$ and $100 \%$ for $\mathrm{Na}^{+}$and $\mathrm{Cl}$, respectively, were observed. The non-sea-salt fraction contributes almost all the $\mathrm{K}^{+}(93 \%)$ and $\mathrm{Ca}^{2+}(90 \%)$ and significantly for $\mathrm{Mg}^{2+}(66 \%)$ and $\mathrm{SO}_{4}^{2-}$ (72\%). Concerning the TRT rainwater concentrations, the seasalt fraction accounts for $\mathrm{Cl}^{-}(75 \%), \mathrm{Mg}^{2+}(79 \%), \mathrm{SO}_{4}{ }^{2-}(24 \%)$, and all the $\mathrm{Na}^{+}$. The non-sea-salt fraction accounts for $\mathrm{K}^{+}$ $(85 \%)$ and $\mathrm{Ca}^{2+}(91 \%)$. Therefore for $\mathrm{SNV}$, sea salt is the main source of $\mathrm{Na}^{+}$and $\mathrm{Cl}^{-}$, while in TRT, besides for $\mathrm{Na}^{+}$and $\mathrm{Cl}$, sea salt is an important source for $\mathrm{Mg}^{2+}$ and contributes with some $\mathrm{SO}_{4}^{2-}$.

Table 6. Regression Analyses and Significance Test Results Between Sea-Salt Constituents and Reference $\mathrm{Na}^{+}$Species in Samples for SNV and TRT

\begin{tabular}{lllll}
\hline & $\begin{array}{l}\text { Regression } \\
\text { Parameters }\end{array}$ & $\begin{array}{l}\text { Seawater } \\
\text { Ratio }\end{array}$ & SNV & TRT \\
\hline \multirow{2}{*}{$\mathrm{Mg}^{2+}$} & Corr. & & 0.57 & 0.89 \\
& Slope & 0.227 & $0.33 \pm 0.05$ & $0.26 \pm 0.04$ \\
& Interc. & & $4.16 \pm 1.37$ & $-0.33 \pm 1.12$ \\
& Corr. & & 0.95 & 0.94 \\
$\mathrm{Cl}$ & Slope & 1.16 & $1.08 \pm 0.04$ & $1.08 \pm 0.12$ \\
& Interc. & & $-1.47 \pm 1.06$ & $-2.18 \pm 3.22$ \\
& Corr. & & 0.19 & 0.44 \\
$\mathrm{Ca}^{2+}$ & Slope & 0.0439 & $0.20 \pm 0.14$ & $0.19 \pm 0.19$ \\
& Interc. & & $7.98 \pm 3.12$ & $4.73 \pm 3.34$ \\
& Corr. & & 0.40 & 0.15 \\
$\mathrm{~K}^{+}$ & Slope & 0.0218 & $0.18 \pm 0.04$ & $0.04 \pm 0.09$ \\
& Interc. & & $2.23 \pm 1.19$ & $2.87 \pm 2.41$ \\
& Corr. & & 0.65 & 0.68 \\
$\mathrm{SO}_{4}{ }^{2-}$ & Slope & 0.121 & $0.25 \pm 0.03$ & $0.14 \pm 0.04$ \\
& Interc. & & $1.64 \pm 0.84$ & $1.99 \pm 1.23$ \\
\hline
\end{tabular}

Corr., correlation coefficient; Slope, slope of the regression plus or minus the standard error, Inter., intercept of the regression plus or minus the standard error. Differences are significant at $95 \%$ confidencelevel; units are $\mu \mathrm{eq} \mathrm{L}^{-1}$. 
Table 7. Sea-Salt (SNV-sea, TRT-sea) and Non-Sea-Salt (SNV-non-sea, TRT-non-sea) Fractions for the Rainwater $\left(\mu e q L^{-1}\right)$

\begin{tabular}{lllllll}
\hline & $\mathrm{Na}^{+}$ & $\mathrm{K}^{+}$ & $\mathrm{Mg}^{2+}$ & $\mathrm{Ca}^{2+}$ & $\mathrm{Cl}^{-}$ & $\mathrm{SO}_{4}^{2-}$ \\
\hline Sea Conc. & 485 & 10.6 & 110.2 & 21.4 & 566 & 58.6 \\
SNV-sea & 14.4 & 0.32 & 3.27 & 0.63 & 16.9 & 1.74 \\
SNV-non-sea & 2.20 & 4.40 & 6.27 & 12.1 & - & 4.50 \\
TRT-sea & 16.92 & 0.38 & 3.84 & 0.75 & 19.8 & 2.06 \\
TRT-non-sea & - & 2.15 & 1.00 & 7.31 & 6.57 & 6.42 \\
\hline
\end{tabular}

*Keene at al. [1986]. Sea conc., sea-salt concentration (meq L')

A factor analysis was done to verify the partition and the importance of each source's contribution to the chemicals found in SNV and TRT rainwaters. Factor matrices with varimax rotation, with extraction of four factors for SNV samples, explaining $69 \%$ of the variance, and three factors for TRT samples, explaining $86 \%$, were obtained.

For SNV, no strong preponderance of any factor is observed: factors 1 and 2 explain $50 \%$ of the total variance in rainfall chemical composition, while the remaining two factors explain $19 \%$ of the variance. Factor 1, however, can be associated with a marine source and therefore with regional transport. Factor 2, although presenting low values for the communality of its species, can be associated with biogenic sources linked with processes such as gas-particle conversion $\left(\mathrm{NH}_{4}^{+}, \mathrm{NO}_{3}{ }^{-}\right.$, and $\left.\mathrm{SO}_{4}{ }^{2-}\right)$, and factor 3 can be associated with soil dust, characterized by high values in $\mathrm{Fe}^{3+}$ and $\mathrm{Mn}^{2+}$ loading. Factor 4 explains the vanance of $\mathrm{Zn}^{2+}$ in association with $\mathrm{K}^{+}$, which has already been observed for the dry period for these samples. Therefore it is possible to infer that a contribution from biomass buming is associated with $\mathrm{K}^{+}$ and $\mathrm{Zn}^{2+}$. This factor matrix (Table 8) shows the segregation among the different sources, along with their contributions to the variance of the chemical composition of the SNV rainfall waters. This result indicates that biomass is an important source of chemical species in the SNV rainwater.
The varimax rotated factor matrix calculated for the TRT rainfall samples is presented in Table 9. The results indicate that more than $50 \%$ of the variance is explained by the factor 1 and that the remaining 34\% is explained by factors 2 and 3 . In this case, communality among all the species is high, and only three factors are necessary to explain most of the observed variance $(86 \%)$. The separation in three factors and their association with the three main natural sources is clear (ocean, biomass, and soil dust). Factor 1 may be associated with the ocean (e.g., $\mathrm{Na}^{+}$and $\mathrm{Cl}^{-}$), explaining a larger percentage of the variance when compared with SNV, owing to its near proximity to the coast. Factor 2 can be associated with biogenic sources, and factor 3 , with soil dust

These results allow us to conclude that although the sources for both sites are similar, their partitioning and intensity are distinct. In the savanna region (TRT), nearer to the marine source, the sea-salt component is responsible for about $50 \%$ of the observed variance in the ranfall chemical composition, while the biogenic and soil dust contributions are equivalent. For the region covered with dense forest (SNV), although the marine factor is responsible for most of the variance $(31 \%)$ of the rainfall chemical composition, the factor associated with the biogenic sources is significantly larger than the one associated with the soll dust. Furthermore, for the forest region one more factor was associated with the biomass burning and may be a result of regional transport. To perform a detailed characterization study of each source at both sites and hence to be able to explain the differences found between SNV and TRT rainfall chemistry, a study of the air mass circulation over the region is necessary. Th1s study is important because the rainfall chemical composition has components which include, for instance, incloud processes (e.g., cloud condensation nucle1) and below-cloud processes (e.g., washout of suspended particulate) [Mészarós, 1993]. Moreover, tropical precipitation results usually from heavy thunderstorm showers produced by convective cumulus clusters on horizontal scales of $2 \times 10^{5} \mathrm{~km}^{2}$. The detailed knowledge about the interactions between convective and regional scale motions for each sampling interval and for both

Table 8. Varimax Rotated Factor Matrix for Rainfall Samples Collected at SNV

\begin{tabular}{|c|c|c|c|c|c|}
\hline & \multicolumn{4}{|c|}{ Factor } & \multirow[b]{2}{*}{ Communality } \\
\hline & 1 & 2 & 3 & 4 & \\
\hline $\mathrm{Na}^{+}$ & $0.87760^{*}$ & 0.18810 & 0.18557 & -0.00045 & 0.84001 \\
\hline $\mathrm{K}^{+}$ & 0.64131 & -0.27741 & -0.12812 & $0.33566^{*}$ & 0.61732 \\
\hline $\mathrm{Mg}^{2+}$ & $0.71888^{*}$ & -0.24791 & 0.17137 & 0.01208 & 0.60776 \\
\hline $\mathrm{Ca}^{2+}$ & 0.08619 & 0.01750 & $0.61751^{*}$ & 0.50487 & 0.64395 \\
\hline $\mathrm{NH}_{4}^{+}$ & 0.15746 & $0.33989^{*}$ & -0.39333 & -0.09309 & 0.30369 \\
\hline $\mathrm{Cl}^{-}$ & $0.93735^{*}$ & 0.17661 & 0.16401 & 0.00720 & 0.93676 \\
\hline $\mathrm{NO}_{3}^{-}$ & 0.10087 & $0.76753^{*}$ & 0.01479 & 0.23761 & 0.65596 \\
\hline $\mathrm{SO}_{4}{ }^{2-}$ & $0.78476^{*}$ & $0.38663^{*}$ & -0.01940 & -0.01781 & 0.76602 \\
\hline $\mathrm{Al}^{3+}$ & 0.01966 & -0.80089 & 0.12870 & 0.24876 & 0.72026 \\
\hline $\mathrm{Fe}^{3+}$ & 0.10842 & -0.18618 & $0.66731^{*}$ & -0.04306 & 0.49358 \\
\hline $\mathrm{Mn}^{2+}$ & 0.38143 & 0.25119 & $0.67155^{*}$ & -0.08495 & 0.66678 \\
\hline $\mathrm{Zn}^{2+}$ & 0.3537 & -0.00877 & 0.01019 & $0.89495^{*}$ & 0.80237 \\
\hline Variance \% & 31 & 16 & 10 & 9 & \\
\hline
\end{tabular}

*Values considered to be high loading. 
Table 9. Varimax Rotated Factor Matrix for Rainfall Samples Collected at TRT

\begin{tabular}{lllll}
\hline & \multicolumn{3}{c}{ Factor } & \\
\cline { 2 - 4 } & 1 & 2 & 3 & Communality \\
\hline $\mathrm{Na}^{+}$ & $0.91793^{*}$ & 0.10123 & 0.17760 & 0.88438 \\
$\mathrm{~K}^{+}$ & -0.03932 & $0.93383^{*}$ & 0.25012 & 0.93614 \\
$\mathrm{Mg}^{2+}$ & $0.86142^{*}$ & 0.12022 & 0.42643 & 0.93834 \\
$\mathrm{Ca}^{2+}$ & 0.27990 & 0.08911 & $0.85490^{*}$ & 0.81714 \\
$\mathrm{NH}_{4}{ }^{+}$ & 0.19613 & $0.94815^{*}$ & 0.07977 & 0.94381 \\
$\mathrm{Cl}^{+}$ & $0.96001^{*}$ & 0.23420 & 0.05541 & 0.97953 \\
$\mathrm{NO}_{3}$ & 0.38752 & $0.84907^{*}$ & 0.24699 & 0.93210 \\
$\mathrm{SO}_{4}^{2-}$ & $0.54480^{*}$ & 0.46589 & 0.38861 & 0.66488 \\
$\mathrm{Al}^{3+}$ & -0.04608 & 0.24186 & $0.52153^{*}$ & 0.33262 \\
$\mathrm{Fe}^{3+}$ & -0.39333 & -0.06277 & 0.13793 & 0.17767 \\
$\mathrm{Mn}^{2+}$ & -0.00492 & 0.25703 & $0.73406^{*}$ & 0.60493 \\
$\mathrm{Zn}^{2+}$ & 0.71454 & -0.12980 & $0.73467^{*}$ & 1.06715 \\
$\mathrm{Variance}^{2+}$ & 54 & 21 & 13.5 & \\
\hline
\end{tabular}

*Values considered to be high loading

sites is necessary. These interactions are, for example, related with the sea surface temperatures, diurnal oscillations, boundary layer transport [Paegle, 1987], and local features associated with local circulation such as sea breeze and valley processes [Stull, 1988].

3.3.2. Chemical species deposition in SNV and TRT. The fluxes of the different chemical species are important input of nutrients to each ecosystem, and they may vary as a function of climate, rainfall, and vegetation cover. The annual deposition of each chemical for each site was calculated as the product of the volume-weighted mean values times the precipitation values. These results are shown in Table 3 for SNV, while the annual values, at TRT in $\mathrm{kg} \mathrm{ha}^{-1} \mathrm{yr}^{-1}$, are: $\mathrm{H}^{+}=$ $0.07, \mathrm{Na}^{+}=13.9, \mathrm{~K}^{+}=2.32, \mathrm{Mg}^{2+}=1.68, \mathrm{Ca}^{2+}=3.37, \mathrm{NH}_{4}^{+}=$ $5.08, \mathrm{Cl}^{-}=22.2, \mathrm{NO}_{3}{ }^{\circ}=4.81, \mathrm{SO}_{4}{ }^{2-}=5.49, \mathrm{Al}^{3+}=0.28, \mathrm{Fe}^{3+}=$ $0.04, \mathrm{Mn}^{2+}=0.05$, and $\mathrm{Zn}^{2+}=2.61$. These results show that sea-salt-derived species have higher or equivalent deposition at TRT than at SNV, while on the other hand, the biogenic and soil-dust-derived species have higher deposition values at SNV than at TRT. Exception to this behavior is presented by $\mathrm{NH}_{4}^{+}$, for which the deposition is greater at TRT than at SNV, perhaps owing to the large extent of pasture in the TRT region.

\section{Conclusions}

Rainwater chemistry studies associated with individual sites [Freydier et al., 1998; Waterloo et al., 1997] and with wet and dry seasons [Andreae et al., 1990; Forti and MoreiraNordemann, 1991; Eklund et al., 1997] in tropical regions have shown that temporal/spatial differences may be significant and must be considered. Our results show significant rainwater chemistry differences associated with both individual sites and seasonality. SNV concentration values are within the same range as those found in central Amazonia, except for $\mathrm{H}^{+}, \mathrm{NH}_{4}^{+}$, and $\mathrm{NO}_{3}^{-}$which were site dependent, since they are mainly biogenically derived species. The TRT rainfall ionic concentration values are larger than those found in the Venezuelan savanna, except for $\mathrm{H}^{+}, \mathrm{NH}_{4}^{+}$, and $\mathrm{NO}_{3}^{-}$, which are similar in both studies. The observed differences are associated with the sea-salt source, which is expected, because TRT and SNV are nearer the ocean than the central Amazonian region or the Venezuelan savanna. Also the influences of biogenic aerosols and soil dust sources have different patterns, since they are dependent on local land use.

The seasonal differences observed for the SNV site indicate the existence of a distinct pattern in the ionic concentration, as well as in the deposition of each ion. The sea-salt source is equally important in the wet and dry seasons, but the structures of the biogenic and soil dust sources are different in each season. These differences are characterized by the differences between the mean values of $\mathrm{K}^{+}, \mathrm{NO}_{3}^{-}$, and $\mathrm{Zn}^{2+}$ (biomass buming and biogenic aerosols) and the ones of $\mathrm{Al}^{3+}$ and $\mathrm{Mn}^{2+}$ (soil dust). However, the most important difference is related to the biomass-burning signature $\left(\mathrm{K}^{+}\right.$associated with $\left.\mathrm{Zn}^{2+}\right)$, which is an extra source of chemical species during the dry season.

The marine source is the most important for both sites. However, its contribution is larger at TRT than at SNV owing to the relative proximity to the ocean, while the structure of the marine contribution is also different. At SNV, sea salt contributes almost all $\mathrm{Cl}^{-}$and $\mathrm{Na}^{+}$and a small percentage of the other ions, while at TRT sea salt is the main source of $\mathrm{Na}^{+}$, $\mathrm{Cl}, \mathrm{Mg}^{2+}$, and some $\mathrm{SO}_{4}{ }^{2-}$. Considering the other two most important sources for the SNV rainfall, on an annual basis, the biogenic aerosol source dominates the soil dust, while at TRT they are similar.

Acknowledgments. This work was supported within the project CNPq-PADCTII/CIAMB (62.0375/92.2). Additionally, the authors wish to thank the support provided by the Instituto Regional de Desenvolvimento do Amapá and by the Instituto Nacional de Pesquisas Espaciais, through its Amazonian Program. One author, $M$. C. Forti, thanks N. M. Pinto for his permanent work in the field and in the laboratory at Serra do Navio and gratefully acknowledges research grant 300692/93-5 from CNPq. We wish to thank W. McDowell for his patience in reading the manuscript and helpful suggestions and R. Gielow and M. I. F. Faccin for language correction.

\section{References}

Andreae, M. O., and T. W. Andreae, The cycle of biogenic sulfur compounds over Amazon basin, J. Geophys. Res., 93(D2), 1487$1497,1988$.

Andreae, M. O., R. W. Talbot, H. Berresheim, D. J. Jacob and K. M. Beecher, Precipitation chemistry in central Amazonia, J. Geophys. Res., 95(D10), 16,987-16,999, 1990.

Appelo, C. A. J., and D. Postma, Geochemistry, Groundwater and Pollution, 536pp., A. A. Balkema, Brookfield, Vt., 1994.

Eklund, T., W. H. McDowell, and C. M. Pringle, Seasonal variation of tropical precipitation chemistry: La Selva, Costa Rica, Atmos. Environ., 31(23), 3903-3910, 1997.

Eyrolle, F., M. F. Benedetti, J. Y. Benain, and D. Février, Geochim. Cosmochim. Acta, 60, 3643-3648, 1996.

Faissol, S., Atlas do Estado do Amapá, 40pp., Ins. Reg. Des. do Amapá e Cons. Nac. de Geog., Rio de Janeiro, Brazil, 1966.

Fearnside, P. M., Deforestation in Brazilian Amazon: The effect of population and land tenure, Ambio, 22(8), 537-545, 1993.

Filoso, S., M. R. Williams, and J. M. Melack, Composition and deposition of throughfall in a flooded forest archipelago (Negro River, Brazil), Biogeochemistry, 45, 109-195, 1999.

Forti, M. C., and L. M. Moreira-Nordemann, Rainwater and throughfall chemistry in a "terra firme" rain forest: Central Amazonia, J. Geophys. Res., 96(D4), 7415-7421, 1991.

Forti, M. C., and C. Neal, Spatial variability of throughfall chemistry in a tropical rain forest (central Amazonia, Brazil), Sci. Total Environ., 120, 245-259, 1992. 
Forti, M. C., A. J. Melfi, and P. R. N. Amorim, Hidroquímica das águas de drenagem de uma pequena bacia hidrográfica no Nordeste da Amazônia: Efeitos da sazonalidade (Estado do Amapá BR), Geoquim. Bras., 11(3), 325-340, 1997.

Forti, M. C., R. Boulet, A. J. Melfi, and C. Neal, Hydrogeochemistry of a small catchment in northeastern Amazonia: A comparison between natural with deforested parts of the catchment (Serra do Navio, Amapá State, Brazil), Water Air Soil Pollut., 118, 263-279, 2000.

Fostier, A.-H., M. C. Forti, J. R. Guimarães, A. J. Melfi, R. Boulet, J. F. and Krug, J. F. Mercury fluxes in a tropical forested small catchment (Serra do Navio, Amapá State, Brazil), in Proceedings of the 5th International Conference Mercury as a Global Pollutant, pp. 23-28, CETEM/CNPq, Biblioteca Ilha do Fundão, Rio de Janeiro, Brazil, 1999.

Freydier, R., B. Dupre, and J. P. Lacaux, Precipitation chemistry in intertropical Africa, Atmos. Environ., 32(4), 749-765, 1998.

Gaudichet, A., F. Echalar, B. Chatenet, J. P. Quisefit, G. Malingre, H. Cachier, P. Buat-Menard, P. Artaxo, and W. Maenhaut, Trace elements in tropical African savannah biomass burning aerosols, J. Atmos. Chem., 22, 19-39, 1995

Gillet, R. W., and G. P. Ayers, The use of thymol as a biocide in rainwater samples, Atmos. Environ., 25A(12), 2677-2681, 1991

Keene, W. C., A. A. P. Pszenny, J. M. Galloway, and M. E. Hawley, Sea-salt corrections and interpretation of constituent ratios in marine precipitation, J. Geophys. Res., 91(D6), 6647-6658, 1986.

Lacaux, J. P., R. Delmas, G. Kouadio, B. Cros, and M. O. Andreae, Precipitation chemistry in the Mayombé forest of equatorial Africa, J. Geophys. Res., 97(D6), 6195-6206, 1992.

Lesack, L. F. W', and J. M. Melack, The depusition, compositioin, and potential sources of major ionic solutes in rain in central Amazon basin, Water Resour. Res., 27, 2953-2977, 1991.

Lesack, L. F. W., and J. M. Melack, Mass balance of major solutes in a rainforest catchment in the central Amazon: Implications for nutrient budgets in tropical rainforest, Biogeochemistry, 32. 115$142,1996$.

Matson, P. A., W. H. McDowell, A. R. Townsend, and P. M Vitousek, The globalization of $\mathrm{N}$ deposition: Ecosystem consequences in tropical environments. Biogeochemistry, 46(1), 67-83, 1999.

McDowell, W., C. G. Sanchez, C. E. Asbury, and C. R. R. Pérez, Influence of sea salt aerosols and long range transport on precipitation chemistry at El Verde, Puerto Rico, Atmos. Environ., 24A(11), 2813-2821, 1990.

Melfi, A. J. (Coordinator), Estudo do ciclo do mercúrio no ecossistema da floresta Amazônica: Avaliação do impacto da mineração de ouro com utilização de mercúrio, Rep. $P A D C T / C L A M B-C N P q$ 620375/92.2, 250 pp., NUPEGEL/USP, São Paulo, Brazil, 1997.

Mészarós, E., Global and Regional Changes in Atmospheric Composition, 175 pp., Lewis, Boca Raton, Fla., 1993.

Morales, J. A., C. Bifano, and A. Escalona, Rainwater chemistry at the western savannah region of the Lake Maracaibo basin, Venezuela, Water Air Soil Pollut., 85, 2325-2330, 1995.

Paegle, J., Interactions between convective and large-scale motions over Amazonia, in The Geophysiology of Amazonia-Vegetation and Climate Interactions, edited by R. E. Dickinson, pp. 347-390, John Wiley, New York, 1987.

Ratisbona, L. R., The Climate of Brazil, in World Survey of Climatology, vol.12, Climates of Central and South America, pp. 219-269, Elsevier Sci., New York, 1976.

Robson, A. J., and C. Neal, Regional water quality of river Tweed, Sci. Total Environ., 194/195, 173-192, 1997.

Stull, R. B., An Introduction to Boundary Layer Meteorology, 666 pp. Kluwer Acad., Norwell, Mass., 1988.

Talbot, R. W., M. O. Andreae, H. Berresheim, D. J. Jacob, and K. M. Beecher, Sources and sinks of formic, acetic, and pyruvic acids over central Amazonia, 2, Wet season, J. Geophys. Res., 95(D10), $16,799-16,811,1990$

Waterloo, M. J., J. Schellekens, L. A. Bruijnzeel, H. F. Vugts, P. N. Assenberg, and T. T. Rawaqa, Chemistry of bulk precipitation in southwestern Viti Levu, Fiji, J. Trop. Ecol., 13, 427-447, 1997.

Williams, M. R., T. R. Fisher, and J. M. Melack, Chemical composition and deposition of rain in the central Amazon, Brazil, Atmos. Environ., 31(2), 207-217, 1997.

Yâmiasóce, M., Estudo da composiçẫo clementar î̂nica de aerossóis emitidos em queimadas na Amazônia. Master thesis, Biblioteca CP 66318 IF/USP-São Paulo, São Paulo, Brazil, 1994.

R. Astolfo. IAG/USP-NUPEGEL/USP Depto de Ciências Atmosféricas, CP3386, São Paulo, SP - Brazil, CEP01060-970. (astolfor@usp.br)

M. C. Forti, MCT-INPE/DMS-NUPEGEL/USP, CP515, São José dos Campos, SP - Brazil, CEP 12201-970. (forti@met.inpe br) A.-H. Fostier, IQ/UNICAMP, CP 6154, Campinas, SP - Brazil, CEP 13083-970. (fostier@iqm.unicamp.br)

A. J. Melfi, ESALQ/USP-NUPEGEL/USP Depto. de Solos e Nutrição de Plantas, CP 09, Piracicaba, SP - Brazil, CEP13418-900. (ajmelfi@usp.br)

(Received October 28, 1999; revised April 10, 2000; accepted April 12, 2000) 